\title{
"A word from man to man". Interwar Venereal Disease Education Films for Military Audiences in France
}

\section{Christian Bonah}

This research received support from the Excellence Initiative of the University of Strasbourg funded by the French government's Future Investments program. It was conducted with the support of Interreg IV Upper Rhine OS A25 Rhinfilm project, co-financed by the European Union - European Regional Development Fund (FEDER) “Transcending borders with every project" and the ANR project MEDFILM. We are grateful for copy-editing by Jean-Yves Bart.

\section{Summary}

In the 1910s, in the wake of the glorious decade of syphilography (1900-1910), the early health education films lay the groundwork for a pragmatic approach to the containment of venereal diseases combining (early) diagnosis, treatment and prophylaxis. Realizing that WWI was turning into a durable military conflict, the French Army created a Cinematographic Section (SCA) in 1915 for the purposes of war propaganda and documentation. In 1916, secretary of war Justin Godard declared syphilis a "national public danger" and initiated information campaigns in military and civilian spheres. Conferences accompanied with film screenings were organized for all new military recruits, resulting in the production of a series sex hygiene films for military audiences characterized by a short, evocative and precise documentary style, contrasting with the romantic sex hygiene films aimed at the general public. This contribution examines the cinematographic origins of the instructional films for the military, as well as their evolution up to WWII

Christian Bonah, Institut des Etudes Avancées de l'Université de Strasbourg SAGE, UMR 7363 Sociétés, acteurs, gouvernements en Europe, Faculté de Médecine, Université de Strasbourg, 4 rue Kirschleger, 67085 Strasbourg Cedex (bonah@unistra.fr) 
and their influence on public sex hygiene films for civilians in the interwar period in France.

Keywords: sex hygiene films, military education, VD education, France, Germany, public health, Section cinematographique de l'Armée

When Lucien Viborel, a leading French specialist of health education, published a 700 page handbook on Modern techniques of social hygiene propaganda in 1930, he included a section on what health education should and should not be, in which he stated that "films, as all means of education, should be clear and minutely adapted to their environment". ${ }^{1}$ Viborel defined social hygiene propaganda as "the art of propagating, disseminating, vulgarizing and spreading, in one word of popularizing an idea utilizing factual knowledge". ${ }^{2}$ In a section on doctrines, tools and texts for sanitary defence, his handbook proposed a list of special audiences to be addressed including educators, railwaymen, sailors, postal workers, industrials and labour unions. The list did not mention the more obvious group of military soldiers. Twelve years after the end of World War I, this suggests that the French health agitator considered educational films for the specific audience of military soldiers to be distinct from health education in schools and the "general public" treated in his handbook.

Taking Viborel's observation that films needed to be "minutely adapted to their environment" seriously, this contribution inquires if, when, how and why venereal disease (VD) prevention films for the military sphere were adapted to their specific audience. The paper also examines the continued production of military VD films during the interwar period in France, which was left unacknowledged by Viborel. In doing so, it also addresses how these films differed from VD films for the general public.

As exemplified by the story of the VD prevention films produced by the United States Armed Forces Commission on Training Camp Activities (CTCA), ${ }^{3}$ films initially produced for a military audience crossed boundaries into the public sphere after WWI. There they provoked heated debates about their acceptability and status, eventually leading to supervision and censorship. ${ }^{4}$ As message films - meaning here that they were made for other reasons than entertainment or art - health prevention films can be studied

1 Viborel 1930.

2 Viborel 1930, 404.

3 See the introduction of the thematic section for more detail. Brownlow 1990; Schaefer 1999, $24-27$.

4 Schaefer 1999; Eberwein 1999; Kuhn 1988. 
on the basis of their intent, of what they meant to the stakeholders involved in their production or of their reception by audiences. Leaving aside the more challenging topic of audience reception, this paper examines the mise en scène of a medical discourse for military audience films, evidenced in the commissioning and production of the films. ${ }^{5}$ In order to analyze the messages that appeared onscreen in detail, the paper will first address the medical context of VD in the 1910s, which provided some of the content. Reference to the cinematographic context of medical film during WWI then helps us pinpoint the origins of early military VD films. Secondly, we describe a corpus of French VD films for medical audiences and their specificities. For practical reasons, our corpus consists of five films that remain in the possession of the French military film archives. Thirdly, we analyze how the mise en scène evolved in form and content between WWI and WWII.

To be clear, I do not claim that these films were the only cinematic vehicles informing soldiers. As civilians, soldiers may have also watched other productions. The paper strives to analyze the strategies and intentions of the military institution regarding VD prevention and control. ${ }^{6}$ Yet, films were not the only means of communication employed; there were also brochures, lectures, posters, postcards and radio shows. The diversity and richness of other mediums, such as the advice booklet Ce qu'il faut savoir de la syphilis by Major Spillmann, ${ }^{7}$ suggest that is necessary to consider these films and their objectives within a wider context. ${ }^{8}$

This paper is based on the analysis of a coherent corpus of five films produced and screened for a specific audience: military men. The existence of these films suggests that motion pictures serving as educational propaganda vehicles were adapted to this specific audience at a very early stage. In the case of VD prevention in the military this meant that films proposed views that were deemed inacceptable for general audiences including women or minors. The films analysed here portrayed views of, and for, a world of men and as part of a military worldview and hierarchy - we need to keep this mind - when analysing them. In chronological order I will provide a comparative account of the propaganda strategies employed in four French films produced between 1918 and 1939. To conclude, the comparison will include the film Ein Wort von Mann zu Mann /A word from man to man (Germany,

5 ECPAD, the Agence d'images du ministère de la Défense created in 1915, holds nearly 30000 military films. We thank them for their support and assistance in accessing films and archives for this project. For more information: www.ecpad.fr. ECPAD also kindly allowed us to make the films mentioned in this paper available for viewing at medfilm.unistra.fr.

6 Rasmussen 2014.

7 Spillmann 1916.

8 Roynette 2000. 
1941), which was included in the corpus of the French military film archives for contingent historical reasons: this German film was produced and screened at the time of Vichy France and German occupation during WWII.

\section{WWI, medical knowledge and cinematic sanitary defence against VD}

In all Western belligerent countries, WWI marked a turning point for venereal diseases and for health education campaigns against them. War-fostered diseases including syphilis and blennorrhoea, two sexually transmitted infectious diseases, became considered as "public dangers", leading governments and army representatives to declare "war on VD", adding a prophylactic war to the military conflict. While it is not my intention to chime in on the historical debates on contemporary statistics on the spread of VD here, ${ }^{9}$ I will merely say that they appear to justify that the situation called for intervention.

Military authorities were mainly divided between those who wanted to punish and others who preferred to persuade. Some members of the United States High Command considered that VDs were avoidable and that contagion was to be considered as the personal and moral fault of the infected soldier. According to military orders, misconduct leading to infection was stigmatized and required punishment. For instance, Austrian military surgeon Hugo Hecht argued that men diagnosed with syphilis should be transferred to the frontlines, and even proposed the creation of special divisions of syphilis-afflicted soldiers specialized in frontline operations. The risk of stigmatization and punishment was such that infected soldiers would keep quiet about their disease as long as possible, thus delaying possible treatment and instigating a cycle of contagion. ${ }^{10}$

On the other hand, other authorities in European and North American armies thought this approach inefficient and searched for more pragmatic ways of tackling the problem. Military authorities launched intensive information and propaganda campaigns against STDs since there was no vaccine or biological prevention for syphilis. These systematic information campaigns were designed to increase awareness and interest. The effort to de-stigmatize

9 A 1918 US manual of military urology presenting a comparative study of VD in Allied Armies gave an estimate of 63000 new cases of syphilis in France in 1916 and over 100000 new cases of VDs in Great Britain in 1917. This amounted to a 50\% annual increase of new contaminations since the beginning of the military conflict in 1914. Young 1918. For a critical appraisal of figures: Rasmussen 2014, 81-122.

10 Harrison 1995; Harrison 2010; Corbin 1977; Grayzel 2003; Sauerteig 1998. 
young soldiers and show an understanding of their situation as they were torn out of their familiar surroundings were pragmatic approaches to promote early diagnosis and treatment without nourishing fear of diseases carrying very loaded connotations and their possible military and civilian consequences. Seizing the opportunity provided by the new medium of motion pictures, army educators used them as educational vehicles, believing that films were an effective channel for educating lay audiences and inspiring them to change both their behaviours and their attitudes. ${ }^{11}$ But what precisely was the information at hand for such audio-visual communication?

If health propaganda was the propagation of hygiene ideas (and ideals) based on scientific knowledge, as Lucien Viborel claimed some ten years later, then what was the factual knowledge available when VD education films started their career? The following table summarizes a short, albeit simplified and generalized, overview juxtaposing "facts" in syphilis research and events in medical film production during what has been called the glorious decade for the understanding of syphilis. ${ }^{12}$

Table 1. The "glorious decade" of syphilography 1900-1910 and the early medical films against VD.

\begin{tabular}{ll}
\hline Medicine / Bacteriology & "Medical films" \\
\hline $\begin{array}{l}\text { 1905 Schaudinn identifies the pale } \\
\text { spirochaete to be the bacteriological } \\
\text { agent causing syphilis }\end{array}$ & $\begin{array}{l}\text { 1898-1900 First medical films are } \\
\text { produced } \\
1902-1907 \text { First health education films } \\
\text { appear }\end{array}$ \\
\hline $\begin{array}{l}\text { 1906-1908 Wassermann et al. invent } \\
\text { and stabilise a serodiagnostic reaction } \\
\text { (BWR) for syphilis }\end{array}$ & $\begin{array}{l}\text { 1908/09 Micro-cinematography } \\
\text { of the spirochaete }\end{array}$ \\
$\begin{array}{l}\text { 1909/10 Paul Ehrlich introduces } \\
\text { Salvarsan as treatment against syphilis }\end{array}$ & $\begin{array}{l}\text { 1914 Early health education films } \\
\text { against VD }\end{array}$ \\
\hline
\end{tabular}

Strikingly, events in the history of VD knowledge and of medical film display a certain chronological relationship, which to some extent explains why films were very quickly adopted in VD prevention to convey hygiene messages. Barely three years after the identification of the causal agent of syphilis, medical films were able to present the microbe as a living and moving entity on a movie screen with micro-cinematography, a technique developed during

11 Lederer/Rogers 2000, 489; Reagan/Tomes/Treichler 2007.

12 Lowy 1993; Lowy 1995; Van den Belt 1997; Brandt 1987.

Gesnerus 72 (2015) 
the first decade of the twentieth century. ${ }^{13}$ Almost all health education films used this technique from WWI and throughout the interwar period. Here emphasis on the link between the history of biomedical sciences and the history of film is needed in order to better understand the form and content of VD prevention films as films of facts. ${ }^{14}$ From a medical history perspective the glorious decade of syphilography was significant in that it established that film propaganda had something to promote beyond moralizing about the dangers of sexually transmitted diseases. Films could spread knowledge about the disease and its causal mechanism, advocate the systematic use of the recently developed chemical-pharmaceutical treatment of syphilis with Paul Ehrlich's preparation 606 named Salvarsan and support prophylactic stations as organizational structures and promote their acceptance despite fear and stigmata of VDs. Films need to be studied in light not only of available knowledge but also of existing medical practices and health care.

November 1914 witnessed the creation of the first military centre for dermatology and VDs under the auspices of Dr. Joseph Nicolas in the $14^{\text {th }}$ military region of France (Lyon). Similar centres were soon opened in all military regions of France. By 1918, twenty fully equipped centres for dermatology and VD and 53 smaller units with over 7000 beds had been set up in France. ${ }^{15}$ Under American influence, they adopted prevention strategies that included the introduction of "prophylactic stations" where soldiers could obtain guidance and undergo preventive antiseptic treatments immediately after a supposed infectious sexual contact (see illustration 2). During the last year of war, Lucien Jame (1891-1969), ${ }^{16}$ a 28-year-old military medical student completed his thesis entitled "Contribution to the study of the prophylaxis of VDs", ${ }^{17}$ in which he made a series of recommendations. Jame called for expanding public education and adding realistic hygiene instructions to the "moral prophylaxis" widely propagated at the time. He also supported the generalization of prophylactic stations for pragmatic and active prevention before and/or after potentially contaminating contacts and recommended that dispensaries for VD offer thorough treatment after infection. Interestingly, the thesis paid little heed to anti-VD films, suggesting that films remained rather marginal vehicles of prevention discourse and practice in France at the time.

13 DePastre/Lefebvre 2012, 91; Gaycken 2015.

14 Boon 2008; Boon 1999.

15 Rasmussen 2014, 372.

16 On Jame's biography see Anonymous 1970; Dobo/Jame 1996.

17 Jame 1919. 
In March 1915 the French army had created the Section cinématographique de l'Armée (SCA) based on an agreement between the four French film majors (Pathé, Gaumont, Éclair and Eclipse) to provide professional film operators to the French army in charge of documenting war scenes for distribution in French newsreels by the majors under military supervision. Their official mission was threefold: to produce war propaganda images illustrating the material and moral power of the French army, to accumulate historical archives documenting war damages by German troops, and to document military life during wartime for military archives, from the everyday experience of soldiers in the trenches to military gear and institutions..$^{18}$ In the context of this cinematic documentation of war over 80 films on medical and sanitary subjects ranging from frontline hospitals and the transport of casualties to clinical films on shell shock were produced. They are now stored in the French military archives. Of particular interest for the present study is a series of twelve clinical films devoted to the symptoms and treatment of shell shock victims. ${ }^{19}$ Including shots of often naked sufferers, the films were used for instructional purposes within military medical services, but also for viewing with soldiers. These films all provide important context to understand the clinical VD films analyzed below.

I will henceforth engage with a corpus of $\mathrm{VD}$ health education films produced and/or screened by the French Army between 1918 and 1941 consisting of the complete selection of VD films held by the central French military archives in Paris (ECPAD). The films, except the first one, were not publically distributed or screened but only used for military training and prevention purposes - this status can be inferred from their production and state of conservation. Yet, a film produced and screened for military audiences may have been screened for others than its initial target audience, as the first French VD film On doit le dire (1918, FR) by Jean Comandon and the American example of the CTCA films clearly indicate. At this stage I have not been able to obtain information about the numbers of copies printed or distribution records. The following table offers a synoptic view of the film corpus under study.

18 Véray, 1995, 42-47.

19 For a list of shell-shock film titles in the ECPAD collection see the filmography at the end. 
Table 2. Synoptic presentation of the film corpus under study, consisting in the collection of health education films against venereal diseases produced between 1918 and 1945 held by the Film archives of the French Army in Paris (ECPAD) ${ }^{20}$

\begin{tabular}{|c|c|c|c|c|}
\hline Title & Date & Audience & Technical data & Director/Producer \\
\hline $\begin{array}{l}\text { On doit le dire } \\
\text { This needs to be said }\end{array}$ & 1918 & $\begin{array}{l}\text { General public / } \\
\text { and military FR }\end{array}$ & $\begin{array}{l}\text { 11' } \\
\text { BW, silent }\end{array}$ & $\begin{array}{l}\text { Jean Comandon } \\
\text { Animation } \\
\text { O'Galop Pathé }\end{array}$ \\
\hline
\end{tabular}

\begin{tabular}{|c|c|c|}
\hline Lésions cutanées & 1918 & Military FR \\
\hline
\end{tabular}

Service Dr. Carle

Skin and venereal

lesions

\begin{tabular}{llll}
\hline $\begin{array}{l}\text { La blénnorragie, } \\
\text { danger social }\end{array}$ & 1933 Military FR & $\begin{array}{l}18 \\
\text { BW, sound }\end{array}$ & Colonel L. Jame
\end{tabular}

Gonorrhea:

a social danger

\begin{tabular}{|c|c|c|c|c|}
\hline $\begin{array}{l}\text { La syphilis, } \\
\text { l'ennemi public } N^{\circ} 1 \\
\text { Syphilis: } \\
\text { Public enemy no. } 1\end{array}$ & 1939 & Military FR & $\begin{array}{l}13 \text { ' } \\
\text { BW, sound }\end{array}$ & Colonel L. Jame \\
\hline $\begin{array}{l}\text { Ein Wort von Mann } \\
\text { zu Mann } \\
\text { A word from man } \\
\text { to man }\end{array}$ & 1941 & Military GER & $\begin{array}{l}25^{\prime} \\
\text { BW, sound }\end{array}$ & $\begin{array}{l}\text { Alfred Stöger/ } \\
\text { Military Academy } \\
\text { \& UFA }\end{array}$ \\
\hline
\end{tabular}

\section{VD teaching and educational films in French military practice}

The military VD films discussed here were made for educational proposes, but it is important to keep in mind that they were commissioned by institutions. As such their contents had to reflect the general philosophy of their commissioning institution. In the case of the French army, it was the aforementioned Lucien Jame who determined guidelines for the films to be produced and used. ${ }^{21}$ Whereas health educators in France, and elsewhere,

20 There is some uncertainty about the dates of the two films by Jame. The film La blénnorragie, danger social is listed as being from 1943 in the ECPAD's files and La syphilis, l'ennemi public $N^{o} 1$ is sometimes dated back to 1940 .

21 By the 1930s Jame was promoted from medical student to Colonel at the Military Health Service at the Val-de-Grâce. Anonymous 1970; Dobo/Jame 1996; Jame 1937. 
generally admitted that sexual hygiene education films should meet public expectations and tastes apprehensions and avoid offending anyone's sense of decency, Lucien Jame and the military institutions he represented took a more pragmatic approach, considering that if the dangers of VD were unavoidable, then the best way to deal with them would be to educate the public and to show the damages they can cause without fostering shame. In practice this meant that educational strategies faced two diverging roads. On the one hand, educators like the scriptwriter of the first French feature length VD prevention film Une maladie sociale, la syphilis produced by Gaumont and directed by Laurent Leredde in 1926, Dr. Louis Devraigne, argued that

public education should avoid horrifying, discouraging and disheartening views. It needs to sweeten the picture ... To be constructive films should insist on beauty and positive features like happy family life. ${ }^{22}$

Quite to the contrary, military instructor and professor at the Val-de-Grâce Lucien Jame expressed the view that

films for military audiences should be modern, forceful and efficient. Unlike the romantic films for the general public that are outmoded, puritan and hypocritical, VD films should be documentary in style: short, evocative and precise. ${ }^{23}$

Before discussing how this played out in practice in the five films analyzed, I will now briefly introduce the films in question. The first one in chronological order, On doit le dire /This needs to be said was released in 1918 and directed by Jean Comandon. The film was commercially produced by Pathé while Comandon was posted at the Buffon military hospital in Paris, where he had been appointed in 1917 and serviced the Central Committee of Assistance to Military Veterans. ${ }^{24}$ The military characters in On doit le dire hint at the initial military setting of the film, even though Pathé distributed the film for general public viewing. This form of cooperation reproduced the initial arrangement between the commercial producers and the army of the SCA between 1915 and 1917. The seven-minute-long black and white film animated by O'Galop tells the story of two military recruits: Mathieu (a French first name) and Matteo (a foreign first name). The moral tale starts with a sequence suggestive of contamination (see illustration 1) and follows the onset of a clinical skin rash, a classical early symptom of syphilis. The recruit Mathieu visits a GP who diagnoses syphilis and proposes treatment and sexual abstinence. A shot of the physician looking through the micro-

22 Devraigne 1928, 337-338.

23 Jame 1937, 390.

24 Between 1918 and 1919 Comandon produced 16 hygiene motion pictures there. He would never again return to this genre. DePastre/Lefebvre 2012. 
scope is followed by realistic micro-cinematography views of the causal agent - the spirochete (see illustration 1).
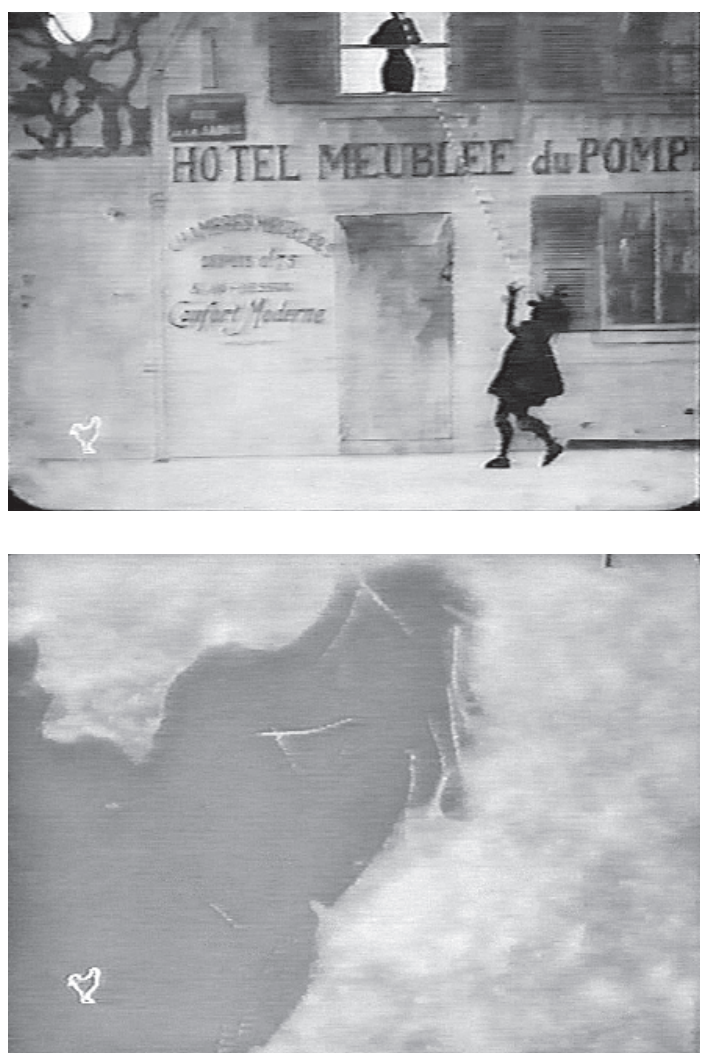

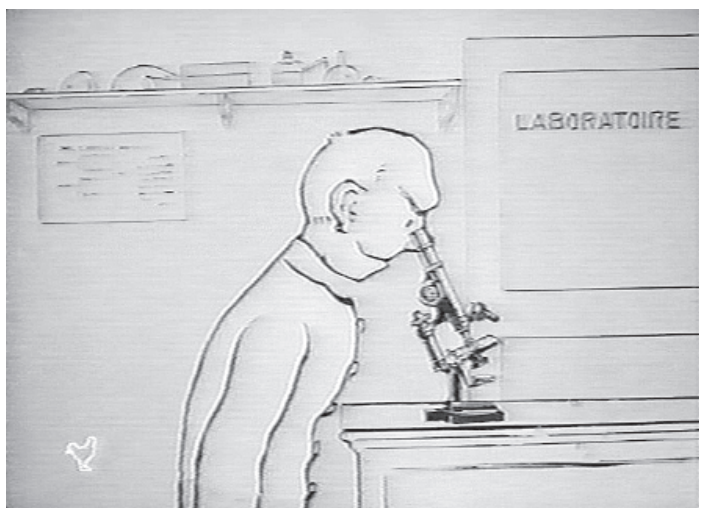

Illustration 1: The moment of contamination, the consultation of a physician leading to a microscopic examination and the view through the microscope with footage from Jean Comandon's research film Spirochaeta pallida shot in 1909. On doit le dire/This needs to be said (France, 1918).

The scientific images interrupt the drama's animated narrative. The film then returns to Matteo, who makes fun of his comrade and does not consult a physician. The consequences of non-treatment are presented in the remainder of the film, which shows the physical damage and degeneration of Matteo's offspring. Using military characters, the film draws on melodrama and slapstick animation of the early silent era. At the same time the film includes realistic footage of scientific lab research. Physical consequences are shown in the form of two short clinical film sequences showing a labial and a limb chancre. Further illustrations of syphilitic complications are shown in the form of animated drawings of dementia and hereditary syphilis including hydrocephalus illustrating a transition from static VD handbook pictures and slide shows to cinematographic presentations through clinical film and scientific animation.

Military centres for dermatology and VDs created in September 1916, following Secretary of War Justin Godart's declaration that syphilis was a public danger, a widespread propaganda campaign against VD that included 
systematic mandatory VD education conferences for new recruits. Alongside information booklets such as "Be aware of VDs" produced for and distributed to military recruits, these conferences regularly employed VD education films "demonstrating and best illustrating lectures that should be simple and familiar". ${ }^{25}$ Initially these films were provided by the Musée Pédagogique, an institution for popular education created in 1879 by Jules Ferry, which started health education film production and distribution before WWI. By the time the United States entered WWI in 1917, US influence further extended film use through the Rockefeller Mission and its engagement for public health propaganda. The US would go on to become the country that used motion pictures for sanitary prevention in the most extensive and effective way. $^{26}$

The second French film used for military VD prevention is of a completely different nature. Lésions cutanées et vénériennes: Service Dr. Carle/Skin and venereal lesions (1918) produced by the cinematographic section of the French army the same year as On doit le dire is a 6-minute silent black and white clinical teaching film. Lacking a narrative structure, the film consists in a succession of clinical shots (see illustration 2). Intertitles are used to announce diseases or symptoms followed by illustrative images. One half of the film is dedicated to skin lesions and syphilis, including a sequence identical to the clinical film sequence in On doit le dire, and the other half is devoted to prophylactic stations (see illustration 2). ${ }^{27}$

25 Rasmussen 2014, 374.

26 As a part of this effort and within a very short timespan, the Medical Department of the US Army established a production facility for medical films that was unprecedented in terms of scope and complexity. An Army Motion Picture Section was established in August 1917 and the Committee on Public Information initiated large-scale production of films to be shown in theatres. By order of the Surgeon General, the Art Department of the Army Medical Museum expanded and established a new section, the Instruction Laboratory, within the Museum in November 1917. From the end of 1917 to March 1919, the Instruction Laboratory produced or participated in the production of some 70 to 100 medical motion pictures. Production included the above-mentioned films of the CTCA, like Fit to Win (1917/18) directed by E. H. Griffith, reissued in 1919, or Gonorrhoea in the Male: Diagnostic and Treatment Techniques (ca. 1918). Some of these films formed the basis for the American Commission for Preservation against Tuberculosis - Mission Rockefeller that initiated American health education methods in France at the end of World War I. See: Nichtenhauser 1954, 162. Lefebvre 1996: Viborel 1930, 38-44.

27 The version of the film preserved at the ECPAD archives is part of a double feature. The second film addresses colonial diseases and colonial troops: Maladies exotiques chez les contingents indigènes. 

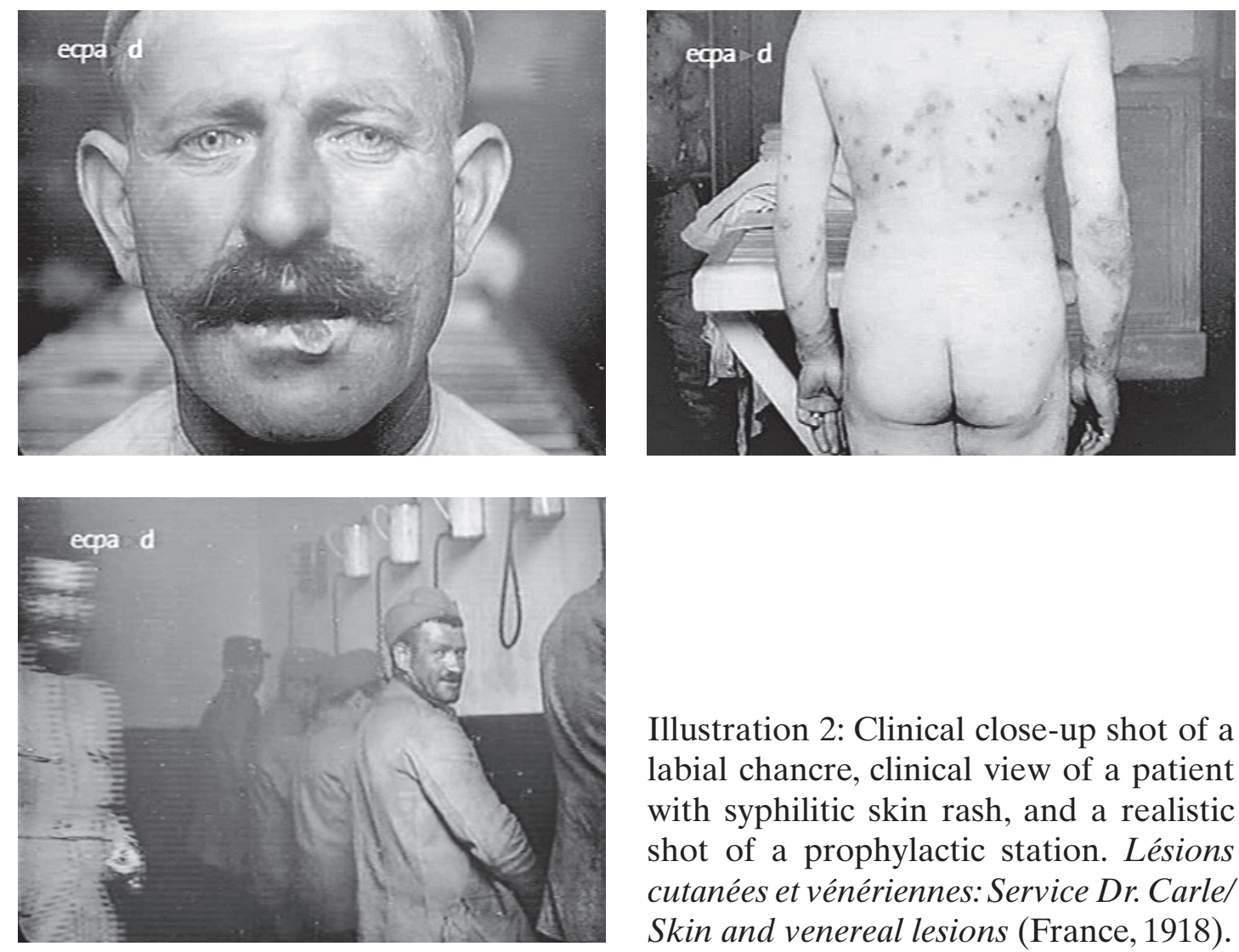

Illustration 2: Clinical close-up shot of a labial chancre, clinical view of a patient with syphilitic skin rash, and a realistic shot of a prophylactic station. Lésions cutanées et vénériennes: Service Dr. Carle/ Skin and venereal lesions (France, 1918).

The film harks back to the clinical teaching films of the first two decades of the century ${ }^{28}$ as produced in clinics since 1905 by W.G. Chase in Boston (United States), Hans Hennes in Bonn and Paul Schuster in Berlin (Germany) documenting motor dysfunctions in neurological patients, or H.C. Thomson in Great Britain and Paul Sainton in Paris (France) who recorded similar symptoms. Yet, it needs to be replaced within the local cinematographic context. Since 1915 the SCA produced clinical films on war neuroses and their treatment, which were used for clinical information and for screening to soldiers and sometimes afflicted veterans for prevention and treatment. Echoing productions like Troubles fonctionnels, service du Dr. Sollier à Lyon (SCA,1917) or Troubles nerveux chez les commotionnés, Val de Grâce (SCA, 1915/16), Lésions cutanées et vénériennes: Service Dr. Carle seems to fall within a line of military clinical film productions sparked by the documentation of war-induced shell shock patients and characterized by bold and shocking shots of disability and nudity.

28 Bonah/Laukötter 2009. 

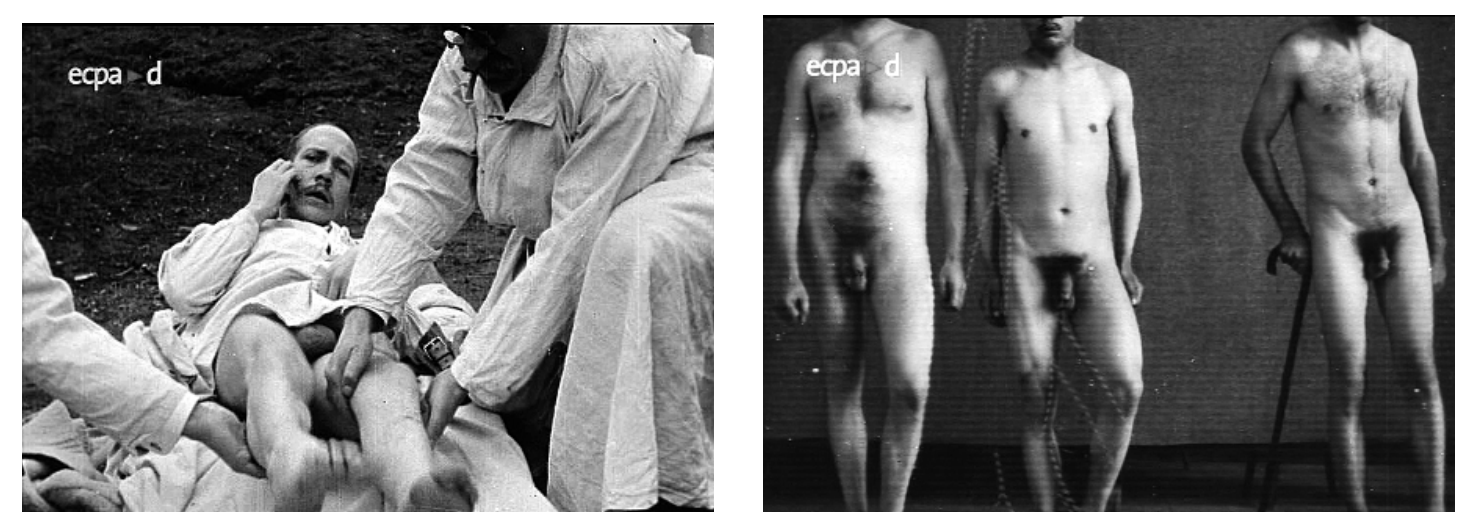

Illustration 3: Clinical teaching film production line of the SCA between 1915 and 1918. Three images from Troubles nerveux chez les commotionnés, Val de Grâce (SCA, 1915/16), Troubles fonctionnels, service du Dr. Sollier à Lyon (SCA, 1917) and Lésions cutanées et vénériennes: Service Dr. Carle/Skin and venereal lesions (France, 1918).

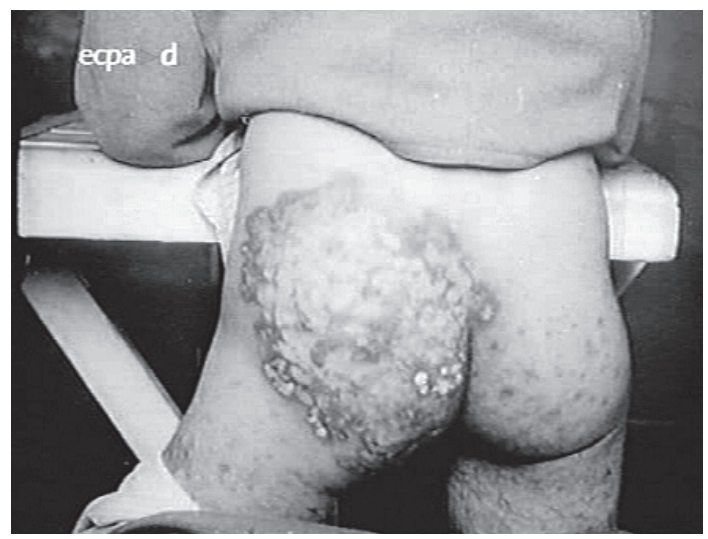

The two 1918 films presented so far marked the beginning of audiencespecific VD prevention film production for the French military sphere. On doit le dire exemplifies a narrative approach. In contrast, Lésions cutanées et vénériennes showcases a factual and instructional approach to a health talk illustrated by a teaching film, based on VD clinical films that initially served medical training. Originating in pictures and static shots of VD used since the late nineteenth century in lantern shows supporting prevention lectures these static images were replaced in clinical films like Lésions cutanées by the technically more sophisticated presentation of pictures in motion considered as "best demonstrating and illustrating" ${ }^{29}$ the words being spoken. Although it is a motion picture, Lésions cutanées et vénériennes remained an accompaniment to an oral presentation.

The third film, released fifteen years later, has elements reflecting the technical and conceptual advances in motion pictures of the 1920s. Blennorragie:

29 Circulaire du 25 septembre 1916. Archives Service de santé des armées, 858. Cited after Rasmussen 2014, 374. 

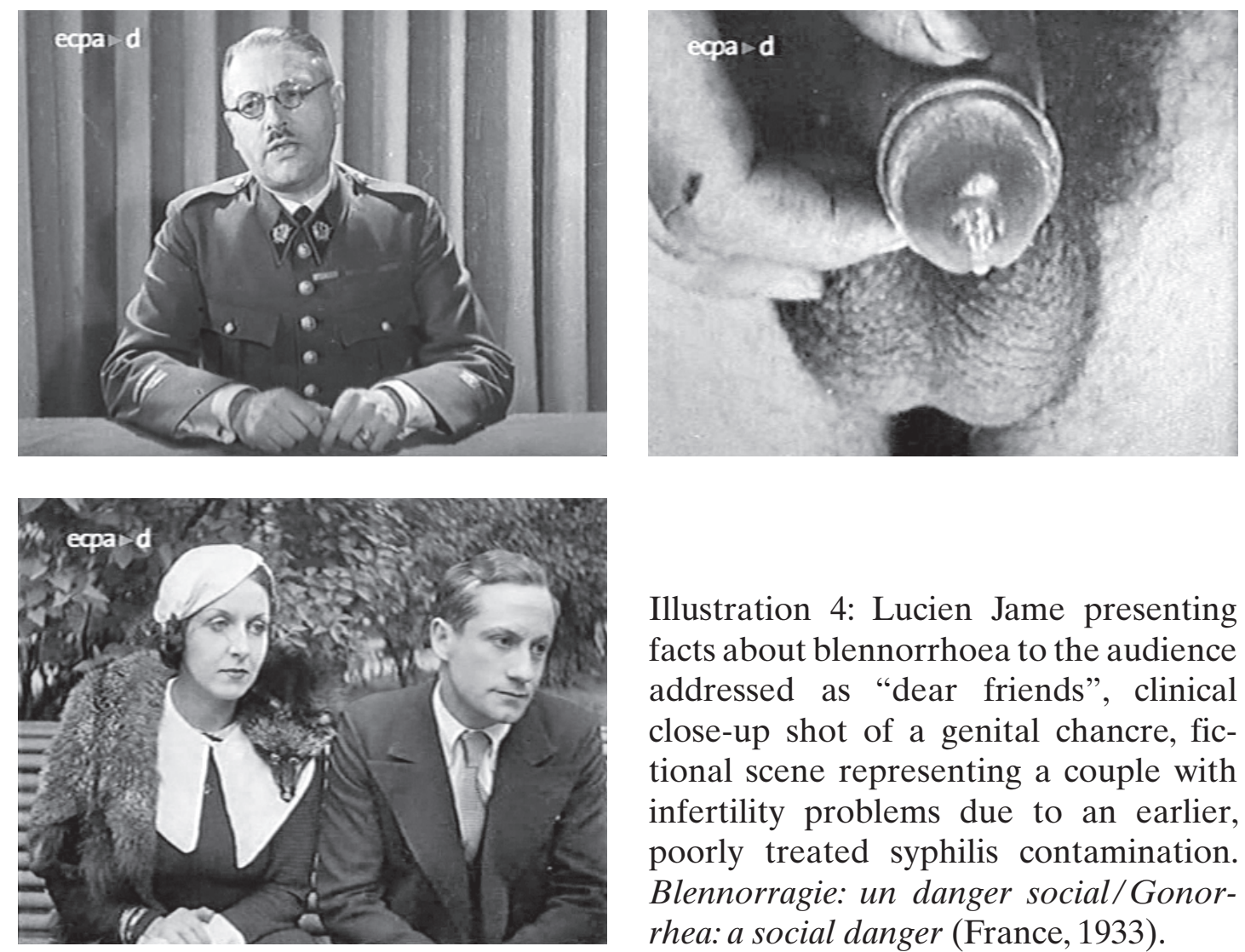

Illustration 4: Lucien Jame presenting facts about blennorrhoea to the audience addressed as "dear friends", clinical close-up shot of a genital chancre, fictional scene representing a couple with infertility problems due to an earlier, poorly treated syphilis contamination. Blennorragie: un danger social/Gonorrhea: a social danger (France, 1933).

un danger social/Gonorrhea: a social danger (1933) is an 18-minute still black and white film with sound. Produced by Colonel Lucien Jame for the French Army, the film presents its director himself lecturing about syphilis. In the format of a filmed conference the speaker directly addresses his audience (see illustration 4). The factual film mixes a variety of shots ranging from clinical close-ups and realistic views of genitals to animated images of human anatomy, and from realistic scenes of prophylactic stations to short fictional vignettes representing sterility and "dangerous women". The director addresses viewers directly as "dear friends", in a deliberate bid to distance him from the military hierarchy. Microscopic views of bacteria are drawings and not micro cinematographic views.

The second film, produced by Lucien Jame in 1939, Syphilis: l'ennemi public $N^{o}$ 1/Syphilis Public Enemy no. 1, is a 13-minute black and white sound picture. In this institutional commission, we can see that the propaganda techniques of instructional films have become more elaborate. The filmed conference style remains but facts are increasingly presented by a voice-over. The film is more didactic than its 1933 predecessor, outlining a step-by-step 

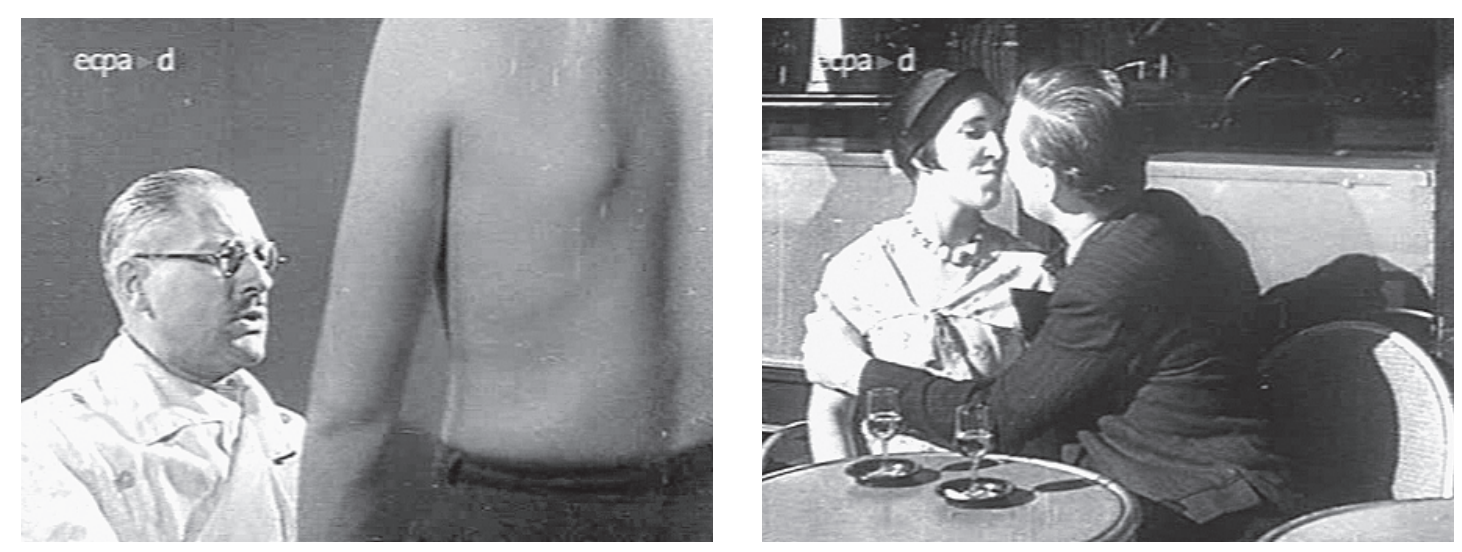

Illustration 5: Lucien Jame, film director, playing a consulting physician in the film. The scene shows him informing a patient as if he were advising a peer, rather than as a person of authority instructing a subordinate. The moment of contamination is depicted in a fictional shot and in an animated shot: A fatal kiss that kills. Syphilis: l'ennemi public $N^{o} 1 /$ Syphilis: Public Enemy no. 1 (France, 1939).

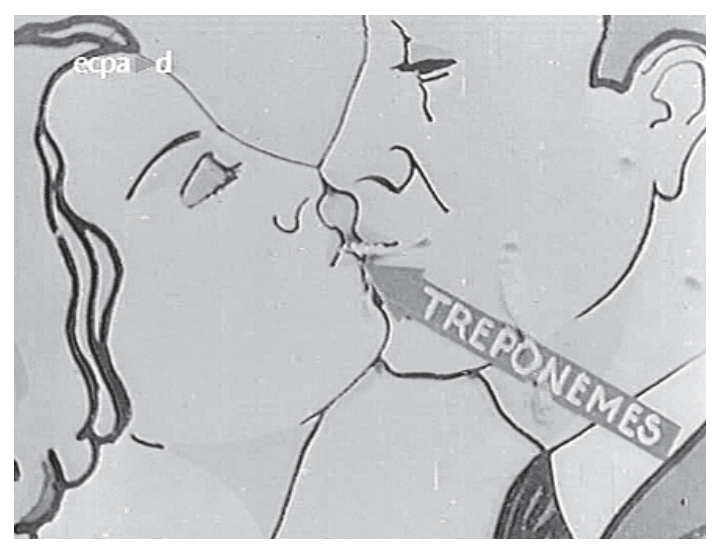

"natural history" of syphilis, concluding with its complications and degeneration. There are more fictional passages, often combined with explanatory animated scenes (see illustration 5). Crude clinical shots of syphilis symptoms still serve as warnings, but they are part of a demonstration rather than merely illustrative.

The last film in our corpus is a 25-minute black and white sound film coproduced by the Germany army (Herstellungsgruppe Otto Nay) and UFA, Ein Wort von Mann zu Mann/A word from man to man (1941). This film, produced under National Socialism ${ }^{30}$ and screened under the Vichy regime and during the German occupation of Paris, brings us back to health fiction films. Following the story of an honest woman engaged to a military sergeant, the narrative shows her succumbing to the charms of an irresistible seducer, also a military recruit but of lower rank, and subsequently contracting syphilis (see illustration 6). Doctor appointments are carefully woven into the narrative, subtly advocating early referral to a physician, and conveying

30 Jung/Loiperdinger 2005; Bonah 2006. 

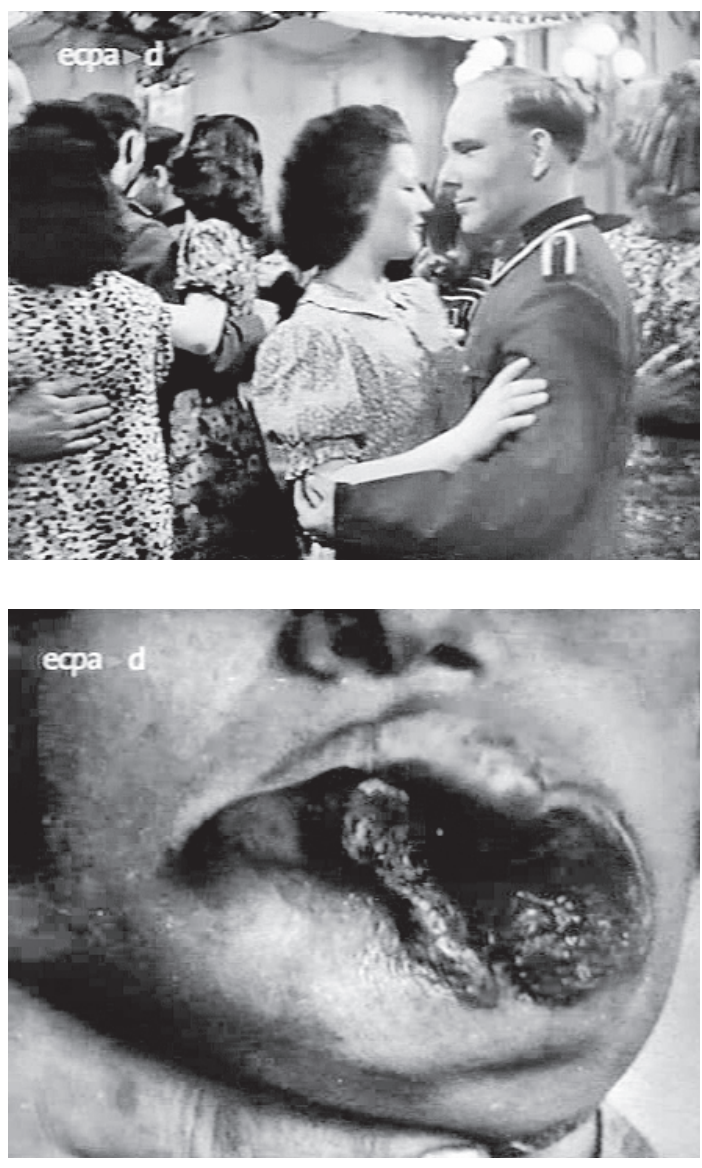

Illustration 6: A moment of seduction and weakness leading to contamination in a purely fictional film setting; Consultation scene illustrating the position adopted by the narrator to spread information about VDs. Physician and patient are standing at equal height and face to face symbolizing friendly advice rather than authority. The film includes two visually similar consultation scenes: one with the woman and one with the man; Fear-inducing clinical shot conveying "information" about the complications of syphilis. Ein Wort von Mann zu Mann/A word from man to man (Germany, 1941).

the message that one should not procrastinate where asking for medical advice is concerned. Early detection in a screening center is presented for both the man and the woman. The film ends with a long period of sexual abstinence and medical observation after treatment, a reconciliation of the couple acknowledging that weakness is human and the postponing of the scheduled wedding. Returning to narration and emotion as vehicles for VD prevention, the film marks a complete break away from the instructional lecture genre of the previous three, as well as with the usual narrative of lower-class women of dubious morality infecting men in service. ${ }^{31}$ In Ein Wort von Mann zu Mann the lower-class male soldier is the human vehicle - after the relapse of an insufficiently treated primary syphilitic infection - trans-

31 For a parallel with the general audience VD prevention film in Germany, see Anja Laukötter's contribution to this volume. 
mitting the disease to the future bride of one of his superiors. No judgment is suggested to the spectator neither about the seducer and contaminator, nor about the failings of the bride to be. Clinical evidence of later stage consequences of untreated syphilis is presented - using particularly brutal and crude shots (see illustration 6) - only in a short two-minute sequence at the very end of the film. Interrupting the emotional narrative as little and late as possible, they are placed as the factual biomedical climax and moral lesson concluding the plot. They reflect the film's overall shot at entertainment, being intended to scare and warn the viewer rather than to provide actual information about syphilis (see illustration 6). The central message of the film revolves entirely around the early detection message "do not procrastinate - go and see your doctor for quick diagnosis and treatment".

\section{Strategies and contradictions of military VD prevention films}

Before delving into a comparison of the films, I will further establish what it is that we are comparing. First, three of the five films show how military VD prevention films evolved visually between 1918 and 1939, from illustrations of public conferences to "short, evocative and precise" 32 visual evidence of "facts". Indeed Lucien Viborel, at the end of his career as health official and looking back on almost half a century of sanitary education experience, argued that:

Sanitary education should take an eminently realistic and practical stance. [...] It can be neither bookish knowledge, nor moral lecturing. To face things, to tell the truth even if it is unpleasant, even if it hurts interests or prejudices, to free oneself from routine, conformism and false shame whenever public health commands it, that is the essence of sanitary education. $^{33}$

The military VD prevention films presented here followed this precept to a degree. The two narrative and the three instructional films all distanced themselves from the cautionary tale model that dominated commercial and general public health education films against VDs. While the 1918 film On doit le dire remained considerably influenced by pre-WWI moralizing films, the four others preferred "realistic" approaches. From a cinematographic perspective these military health education films clearly indicate the origins of their instructional and "realistic" pictures from clinical photography and early clinical film. On doit le dire pioneered the practice of including microcinematographic shots from laboratory research films as well as clinical 
film sequences into fictionalized propaganda films. The same practice featured in the films by Lucien Jame Blennorragie and Syphilis: l'ennemi public $N^{o} 1$. Furthermore, films from Lésions cutanées et vénériennes: Service Dr. Carle to Syphilis: l'ennemi public $N^{o} 1$ clearly display similarities with sanitary films produced by the SCA during WWI that hint at their common origin of visual materials from clinical teaching films documenting WWI medical effects of trauma and shell-shock. These shell shock films had established by 1918 already to major elements of VD prevention films analyzed here:clinical documentation and audience specific screening since the shell shock pictures were shown to traumatized soldiers suffering from functional neurosis, as a means of visual shock treatment and to prevent moral contagion of mental disease when they seemed to reach epidemic proportions. Most significantly the three films produced by the French army illustrate, through their distinctive structure, the roots of factual VD prevention films in spoken conferences. Their structure evolves from a clinical teaching film Lésions cutanées et vénériennes to filmed conferences as in Blennorragie and Syphilis: l'ennemi public $N^{o} 1$ forming a distinct film sub-genre. As instructional prevention films became more sophisticated they progressively erased the traces of their roots and combined multiple sources and forms of conveying factual "information". Didactic considerations mixed fiction vignettes with animation sequences and reduced the presence of a lecturer as films progressively became autonomous and self-sufficient when explaining VD and its dangers. Laboratory documentation/film sequences progressively became played out or embedded in fictionalized scenes, rather than being presented as frontal, straight forward documented views. In this process clinical shots were, when removed from their teaching film context and their accompanying lecture, transformed into mere icons losing some of their initial instructional content. Editing and the consistency of this blend of multiple visual approaches and materials caused considerable concern to producers, who were worried that the films might not appeal to viewers. Abrupt editing cuts disrupted the construction of the seamless flow of images that was usual for fiction or fictionalized film narratives. All of the films analyzed here mixed fiction and fact, thereby blurring the boundary between education and entertainment. The films differed in their respective amounts of fiction and fact the balance depended on the producers and directors' ideological and educational convictions as to whether films should seek to produce conditioned responses in viewers by touching an emotional nerve or rather attempt to convince them through information, reason and knowledge. Regardless of that choice, the images, be it in fiction-heavy films like Ein Wort von Mann zu Mann or in instruction- heavy ones like Syphilis: l'ennemi public $N^{o} 1$, went from being 
mere illustrations of oral discourse to discourses in and of themselves, visually demonstrating all that needed to be seen and known.

A second point of interest for the comparative study of the five films is the question of how they addressed male military viewers to make sure the messages they conveyed would resonate with them. In other words, how could films speak to as many viewers as possible on facts about syphilis in the military, a world structured by hierarchy, obedience, order and punishment for transgression and at that time an essentially male universe? Where military instruction was dominated by strict authority, the two conference films by Lucien Jame Blennorragie and Syphilis strike a different chord. In the very first scene the presenter faces the camera to address the viewers as "dear friends". The author of the film creates an atmosphere of intimacy, comradeship and community in battle. Facts and messages are conveyed in the form of advice by an earnest best friend addressing an individual's sense of understanding responsibility rather than demanding blind obedience. This shift in approach is reflected by visual choices (see illustrations 4 and 5) with physicians either facing their patients on an equal footing (illustrations 4 and 6) or being shown diagonally - using a frontal wide-angle shot rather than a low angle - thus downplaying their power over the patient, who dominates the shot (see illustration 5). Furthermore the films, in their somewhat experimental form, display expressions of real concern as the presenter addresses the spectator with a touch of uneasiness. All the military films analysed here pursue an approach concerned with avoiding blame and reassuring the audience that "it can happen" as opposed to the blaming and shaming over the earlier moralizing films; their core message being simply "Do not hide or procrastinate and go and see a doctor". Adopting a serious and matter-of-fact tone, the instruction films acknowledged that the topic was sensitive. Yet, this military pragmatism foreshadowed the post WWI view of sexuality and VDs as things that can be discussed and shown to combat ignorance. Distancing itself from entertainment, the "a-word-from-man-toman" communication strategy of instructional films like Blennorragie and Syphilis was a moment of educational realism in effort to change human behaviour through reasoning. Still, not everything could be shown onscreen, and the content of the films was not entirely rational. Ideology always seeped in behind the facts. In a predominantly Catholic country and at a time when depopulation was feared, none of the films mentioned condoms as a preventive measure despite their availability at the time. Contamination often remained a taboo: a kiss was the only means of contamination presented, although contamination by sexual intercourse was far more prevalent. Last 
but not least, women were generally depicted as the source of contamination even though men also contaminated women. There was no mention of homosexuality whatsoever in any of the films.

The depiction of men, male sexuality and STDs and likewise of women is another point of interest in these films. Women are conspicuously absent from all of the films analyzed, except for the Nazi-era Ein Wort von Mann zu Mann. In the rare case when they are featured, usually in fiction vignettes like the sequence in Blennorragie and Syphilis, they are characterized as "easy", as sources of contamination or as femmes fatales. Contamination is shown in the form of a harmless kiss, far from desire, lust or even prostitution (see illustration 5). The symbolic "kiss", although as mentioned not the most frequent means of contamination, is the only part of sex and female sexuality that can be shown explicitly. In contrast, clinical views of male genitalia altered by syphilis are frequently found in all the prevention films. From This needs to be said to it should be shown, VD prevention films for military audiences provide a guided tour of the horrors of syphilis to stage the reality of the danger and damage it causes. These images must be understood in light of the background of WWI and clinical shell shock films. Over time they went from serving a purpose of clinical instruction and prevention to being used merely for shock value. The "a-word-from-man-to-man" communication strategy is complemented by visuals shaping a world of tough men, able to tackle VDs head on, from the intimate man-to-man tone of the counsellor to the crude shots of male genitals. Despite its title, the Nazi film Ein Wort von Mann zu Mann broke away from these representations and conventions, with a completely different structural and visual approach. Despite the fact that this is a military instruction film, the film's central character is not a man, but instead an "honest and faithful woman" that loses control in a rash moment. Desire and seduction are portrayed as she succumbs to the charms of a man after he encouraged her to imbibe heavily. Here the contaminator is a male seducer. Information sequences make up barely one tenth of the film, which merely offers a glimpse of the consequences of the disease with visual symbols emptied of their initial informative character, which relied on context. Lastly, this Nazi VD prevention propaganda even subverts the traditional tropes of masculinity prejudices by depicting the male character as tough on the outside but showing him crying in the dormitory as he suffers a relapse of his syphilitic infection. Presenting a realistic approach to contamination and human behaviour the film goes a long way to dismantle stereotypes and fight conformism by showing a woman with strength of character and revealing an inner weakness in the male protagonist. And it is an entirely fictionalized military health education film that 
operates this inversion of social realism avoiding gender stereotypes. Health instruction was propaganda, and by 1941 the Nazi regime had accumulated considerable expertise in the "modern techniques" of that art. Totalitarian abuse of the concept of propaganda - in its interwar meaning of popularizing an idea - has led to the point that propaganda after WWII was no longer considered a modern technique for conveying facts, as the title of Viborel's handbook Modern techniques of social hygiene propaganda cited in the introduction suggests, but as a means of indoctrination and deceit. Sexual hygiene propaganda was then renamed sexual health education, but questions about how to best spread information about disease prevention in order to convince or to condition citizens' behaviour and attitudes remained.

\section{Conclusion}

This corpus of interwar French military instruction films about VDs and their treatment illustrates the pragmatic stance adopted by military physicians. The films display a realistic approach and a pragmatic prevention strategy. They were realistic first in the sense that authors like Lucien Jame advocated a head-on attitude. Cases of VDs increased during war periods to an extent that they could not be simply eradicated or suppressed and prevention needed to start from there. The films were short, precise and to the point - films of fact. Evidently this does not mean that their realism simply consisted in documenting "reality" and that the information they provided was objective and unbiased ${ }^{34}$ it was clearly goal-oriented. Early diagnosis and treatment and the use of approved medication only were the key messages the films promoted. This approach connects these films to strategies also pursued in films for the general public like Feind im Blut. ${ }^{35}$ Although I do not conduct neither a full comparison between general public and audience specific military films, nor between French and German sex hygiene films, my contribution serves as a counterpoint to two papers by Anja Laukötter and Joël Danet in this thematic volume. It therefore argues indirectly and opens a comparative perspective between national settings, France and Germany on the one side, and between general public and special audience oriented films, on the other side.

Military prevention films visually illustrate the transition from silent static accompaniments to health talks to standalone sound movies using a

34 Delage/Guigueno 2004; Jung/ Loiperdinger 2005.

35 See the contribution by Joël Danet in this volume for this point.

Gesnerus 72 (2015) 
genuinely filmic language. ${ }^{36}$ The author of the talk first becomes a character in a film, and ends up only providing a voiceover commenting visual "facts . Factual images finally spoke by and for themselves in a way that differed from words. Propaganda recast itself as "pure" information and education; clinical documents and laboratory shots functioned as visual proof beyond subjective spoken words. But subjectivity and political and institutional goals and ambitions evidently remained and health education films have continued to strive for conditioning audience behaviour and attitudes gently and subtly. Between the early films presented at public fairs and the health propaganda films using fairy tale narratives, these military instructional films against VDs encapsulate a time of instructional utopia, when it was thought that realistically presented rational information (even if it remained evidently biased) could serve as the basis for successful sex education. In the French military world from man to man portrayed here, VDs were linked to stereotypical representations of dangerous women vs happy family lives. Even though they were initially intended to break with the prevailing conformist representations of the 1920s, they reproduced their own flawed systems of social codes and conventions where sexes could be shown but sexuality could not, where women were either good mothers and housewives or otherwise dangerous home wreckers. VD prevention films with lecturers as public words from man to man in a military world of men were buried in WWII and so was non-fiction sanitary propaganda. But the visual presentation of "objective" scientific facts serving as iconic proof has been their enduring legacy.

\section{Filmography}

(Films are available at: medfilm.unistra.fr)

On doit le dire (France, 1918)

Lésions cutanées et vénériennes: Service Dr. Carle (France, 1918)

Blennorragie: un danger social (France, 1933)

Syphilis: l'ennemi public $N^{o} 1$ (France, 1939)

Ein Wort von Mann zu Mann (Germany, 1941)

\section{ECPAD shell shock films}

Centre des psychonévrosés du GMP P. Laignel-Lavastine (France, 1915-1916?)

Fleury les Aubrais. Annexe de neuropsychiatrie de $5^{e}$ Corps d'armée, Service du docteur Rayneau, médecin-major de $1^{\text {ire }}$ classe (France, 1915-1916?)

Troubles nerveux chez les commotionnés, Val de Grâce (France, 1915/16)

Commotionnés au Val de Grâce (France, 1915-1916)

Centre neurologique de la $7^{e}$ Région, station neurologique de Salins, hôpital complémentaire 42 Saint-André, Service des psychonévrosés (France, 1916-1917?)

36 For the persisting and changing role of lectures accompanying sexual hygiene films see Anja Laukötter's contribution to this volume. 
Centre neurologique de la 14 ìme Région, Lyon (France, 1917?)

Troubles fonctionnels, service du Dr. Sollier à Lyon (France, 1917)

Quelque troubles fonctionnels (hystériques chez les commotionnés (France, ND c. 1917)

Traitement des troubles nerveux fonctionnels dans le service du Docteur Clovis Vincent (France, ND c. 1917)

Le progrès de la science française au profit des victimes de guerre, une grande découverte du docteur Vincent (France, 1917)

Troubles fonctionnels chez les commotionnés, hôpital Saint-Charles, Marseille (France, 1917?)

Le centre neurologique de Montpellier. Docteur Villaret (France, 1919)

\section{Bibliography}

Anonymous, “Lucien Jame (1891-1969)", Ann Med Interne (Paris) 121/1 (1970) 110 111

Bonah, Christian/Anja Laukötter, "Moving pictures and medicine in the first half of the $20^{\text {th }}$ century: Some notes on international historical developments and the potential of medical film research", Gesnerus 66 (2009) 121-145

Bonah, Christian/Vincent Lowy, "La propagande sanitaire par le film documentaire en France et en Allemagne. Réflexions à partir de deux exemples du milieu des années 1930: L'œuvre Grancher et Erbkrank", in: Christian Bonah/Anne DanionGrilliat/Josiane Olff-Nathan/Norbert Schappacher (éds), Nazisme, science et médecine (Paris 2006) 167-192

Boon, Timothy, Films and the contestation of public health in interwar Britain, $\mathrm{PhD}$ dissertation, University of London (London 1999)

Boon, Timothy, Films of Fact: A History of Science in Documentary Films and Television (London 2008)

Brandt, Allan, No Magic Bullet. A Social History Venereal Disease in the United States since 1880 (New York/Oxford 1987)

Brownlow, Kevin, Behind the Mask of Innocence: Sex, Violence, Prejudice, Crime: Films of Social Conscience in the Silent Era (New York 1990)

Corbin, Alain, "Le péril vénérien au début du siècle, prophylaxie sanitaire et prophylaxie morale", Recherches 29 (1977) 245-283

Delage, Christian/Vincent Guigueo, L'historien et le film (Paris 2004)

DePastre, Béatrice/Thierry Lefebvre, Filmer la science, comprendre la vie. Le cinéma de Jean Comandon (Paris 2012)

Devraigne, Louis, Vingt-cinq ans de puériculture et d'hygiène sociale (Paris 1928)

Dobo, Nicolas/Pierre Jame, "Le Général Lucien Jame", Histoire des Sciences Médicales 30 (1996) 381-388

Eberwein, Robert, Sex Ed. Film, Video, and the Framework of Desire (New Brunswick 1999)

Gaycken, Oliver, Devices of Curiosity. Early Cinema and Popular Science (Oxford 2015)

Grayzel, Susan, "Liberating Women? Examining Gender, Morality and Sexuality in First World War Britain and France", in: Gail Braybon (ed.), Evidence, History and the Great War (New York 2003) 113-134 
Harrison, Mark, "The British Army and the Problem of Venereal Disease in France and Egypt during the First World War", Medical History, 39 (1995), 133-158

Harrison, Mark, The Medical War. British Military Medicine in the First World War (Oxford 2010)

Jame, Lucien, Contribution à l'étude de la prophylaxie des maladies vénériennes, Medical Dissertation (Lyon 1919)

[Jame, Lucien] Ecole d'application du service militaire du Val-de-Grâce, Cours d'hygiène et de prophylaxie (Paris 1937)

Jung,Uli/Martin Loiperdinger (eds.), Geschichte des dokumentarischen Films in Deutschland. Band 1: Kaiserreich 1895-1918 (Ditzingen 2005)

Kuhn, Annette, Cinema, Censorship and Sexuality, 1909-1925 (London/New York 1988)

Lederer, Susan/ Naomi Rogers, "Media”, in: Roger Cooter/John Pickstone (eds), Medicine in the Twentieth Century (London 2000) 487-502

Lefebvre, Thierry, Cinéma et discours hygiéniste 1890-1930, Thèse de 1'Université de Paris (Paris 1996)

Löwy, Ilana, "Les 〈faits scientifiques〉 et leur public: L'histoire de la détection de la syphilis", Revue de synthèse 116 (1995) 27-54

Löwy, Ilana, "Testing for Sexually Tranmissible Disease, 1907-1970: the History of the Wassermann Reaction", in: Virgina Berridge /Paul Strong (eds.), AIDS and the Contemporary History (Cambridge 1993) 74-92.

Pernick, Martin, S., "Thomas Edison's Tuberculosis Films: Mass Media and Health Propaganda", Hasting Center Report 8 (1978) 21-27

Rasmussen Anne, La Grande Guerre prophylactique. Armée, santé et citoyenneté en France, 1914-1918. Volume 2, Habilitation à diriger des recherches (Strasbourg 2014)

Reagan, Leslie J./Nancy Tomes/Paula A.Treichler, Medicine's Moving Pictures. Medicine, Health, and Bodies in American Film and Television (Rochester 2007)

Roynette, Odile, Bons pour le service. L'expérience de la caserne en France à la fin du XIX siècle (Paris 2000)

Sauerteig, Lutz, "Sex, Medicine and Morality during the First World War", in: Roger Cooter/Mark Harrison/Steve Sturdy (eds), War, Medicine and Modernity (ThruppStroud 1998) 167-188

Schaefer, Eric, Bold! Daring! Shocking! True! A History of Exploitation Films, 1919_ 1959 (Durham/London 1999)

Spillmann, Médecin-major, Ce qu'il faut savoir de la syphilis (Paris 1916)

Van den Belt, Henk, Spirochaetes, serology and salvarsan. Ludwik Fleck and the construction of medical knowledge about syphilis, PhD Thesis Landbouwuniversiteit (Wageningen 1997)

Viborel, Lucien, L'éducation sanitaire (Tours 1953)

Viborel, Lucien, La technique modern des la propagande d'hygiène sociale (Paris 1930)

Young, Manual of military urology (Washington, 1918)

\section{Archives}

Nichtenhauser, Adolf, A History of Medical Film, unpublished manuscript, National Library of Medicine, Nichtenhauser papers, Washington DC (1954) 